\title{
The Subclavius Posticus Muscle: its Phylogenetic Retention and Clinical Relevance
}

\author{
Músculo Subclavio Posticus: Presencia Filogenética y Relevancia Clínica \\ Prakash Shetty; Mangala M. Pai; Latha V. Prabhu; \\ Rajanigandha Vadgaonkar; Soubhagya R. Nayak \& R. Shivanandan
}

SHETTY, P.; PAI, M. M.; PRABHU, L. V.; VADGAONKAR, R.; NAYAK, S. R. \& SHIVANANDAN, R. The subclavius posticus muscle: its phylogenetic retention and clinical relevance. Int. J. Morphol., 24(4):599-600, 2006.

SUMMARY: During routine dissection practice a supernumerary muscle was found on the right side infraclavicular region of a male cadaver. This muscle was arising from the superior surface of the first rib and its coastal cartilage and inserted to a thick ligament that extended from the medial end of the suprascapular notch to the capsule of the acromioclavicular joint. This accessory muscle slip was innervated by a branch from the nerve to subclavius. According to its location and innervation the aberrant muscle was considered to be the subclavius posticus. The anatomic relationships of the muscle make it clinically significant.

KEY WORD: Subclavius posticus muscle; Muscular variation; Hypobranchial musculature; Accessory phrenic nerve.

\section{INTRODUCTION}

The subclavius posticus (chondroscapularis) is an aberrant muscle described by Rossenmuller in 1800 (Akita et al., 2000). This excess intermediary muscle between the subclavius and inferior belly of omohyoid appears to be more closely related to the subclavius, based on the innervation of this muscle (Akita et al., 1996). Conventionally, the proximal attachment is to the first rib and distally to the transverse scapular ligament or/and to the superior margin of the scapula. The muscle described in this case morphologically is suggestive of subclavius posticus however presents a variable anatomy.

\section{CASE REPORT}

An aberrant muscle, subclavius posticus, was revealed in the left infraclavicular region of an adult male cadaver during routine dissection studies. This muscle lying inferior to the subclavius originated from the superior surface of the sternal end of first rib and its coastal cartilage. The muscle belly coursed dorsolaterally beneath the clavicle crossing the axillo- subclavian vessels and the cords of brachial plexus. It then inserted into a considerably thick additional ligament that extended from the medial margin of the suprascapular notch, immediately medial to the attachment of inferior belly of omohyoid and laterally blended with the capsule of the acromioclavicular joint. The suprascapular artery coursed above the ligament whereas the nerve passed below, however both the artery and nerve ran superior to the suprascapular (transverse scapular) ligament. The accessory muscle measuring $16.6 \mathrm{~cm}$ in length received innervation from nerve to subclavius. The presence of accessory phrenic nerve was also noted.

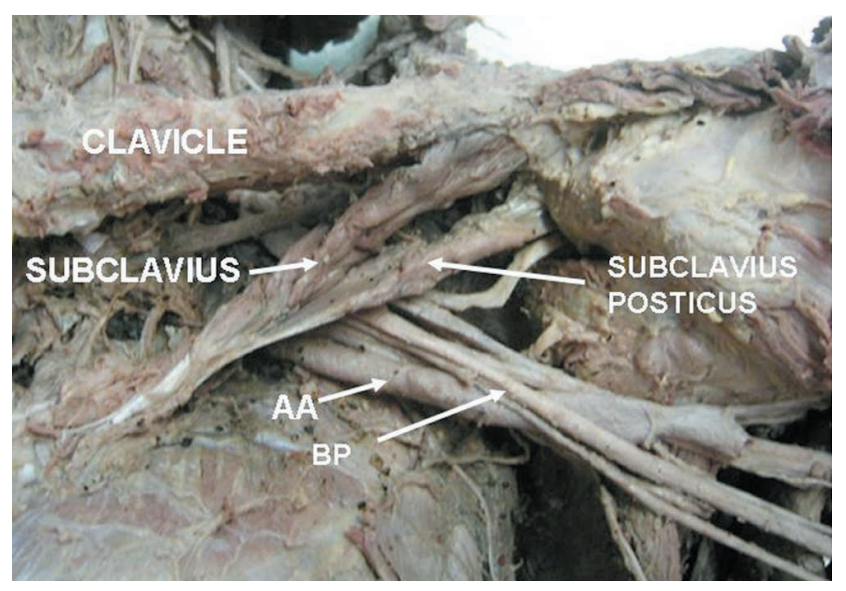

Fig. 1 This photograph shows the left infraclavicular region. The subclavius muscle along with the subclavius posticus is visualized. Note the course of the axillary artery (AA) and the cords of brachial plexus (BP) beneath the above mentioned muscle slip. 


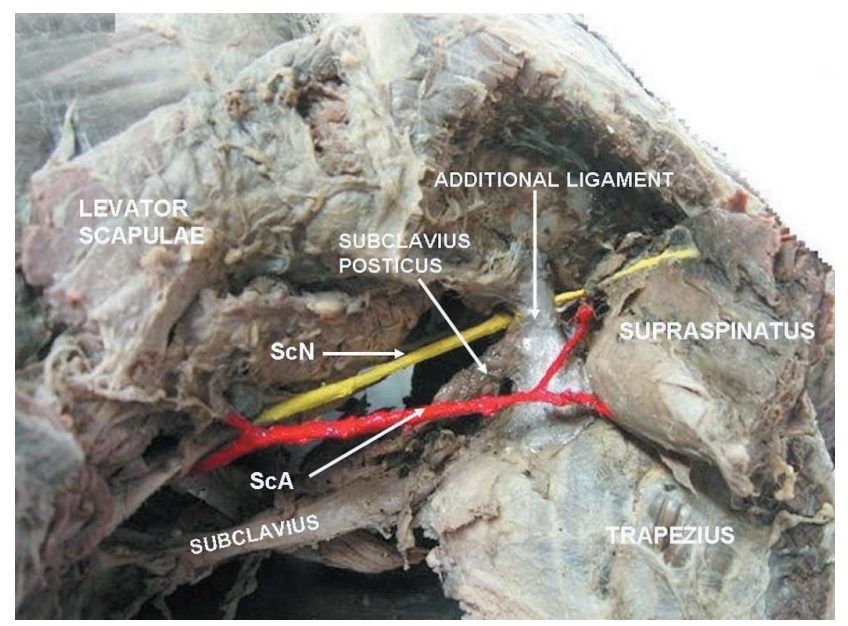

Fig. 2. Postero-superior view of the left shoulder region is seen. Trapezius is reflected superiorly to expose the additional ligament into which the fibres of subclavius posticus are seen to insert. Also note the relation of the suprascapular nerve and artery to the additional ligament.

\section{DISCUSSION}

The existence of the supernumery muscles is well documented and its utilization in muscle reconstruction is well known. It is recommended to take into account the possible existence of an aberrant muscle during examination of patients complaining of symptoms, suggestive of a compression. The anatomical relationships of subclavius posticus with the brachial plexus and the subclavian artery is suggestive of a possible cause of the thoracic outlet syndrome (Forcada et al., 2001) and could be considered as a possible factor causing the Paget-Von Schrotter syndrome which is recognized as spontaneous or effort related thrombosis of the axillosubclavian vein (Akita et al., 2000). The incidence of the aberrant muscle varies in different races. An incidence of $4.8 \%$ is been documented in Japanese cadavers, but is rather a rare entity in other regions, as depicted by available literature. The nerve innervating the muscle is nerve to subclavius as agreed by other authors (Akita et al., 1996, 2000). Insertion of the muscle to the additional ligament blending to the capsule of the acromioclavicular joint may have some bearing on the movements of the shoulder girdle mainly the scapular rotation.

It is speculated that, in Weister rats the subclavius muscle might develop from an analage of the hypobranchial musculature near and / or in the junctional region between the hypobranchial and the pectoral regions of the body trunk. The region might phylogenetically and ontogenetically, concomitantly with the development of the heart and lungs, undergo remarkable changes, to which variations of this muscle and its innervation could be attributed (Tanaka et al., 1998). It is also stated that in rats, the appearance of the accessory phrenic nerve seemed to be an almost consistent phenomenon. The anomalous patterns found in this case could be explained in terms of phylogenetic retention.

\section{SHETTY, P.; PAI, M. M.; PRABHU, L. V.; VADGAONKAR, R.; NAYAK, S. R. \& SHIVANANDAN, R. Músculo subclavio posticus:Presencia} filogenética e importancia clínica. Int. J. Morphol., 24(4):599-600, 2006.

RESUMEN: Durante una disección de rutina, un músculo supernumerario fue encontrado en el lado derecho de la región infraclavicular de una cadáver de sexo masculino. Este músculo se originaba de la superficie superior de la primera costilla y cartílago costal y se insertaba en un grueso ligamento que se extendía desde la parte medial de la incisura supraescapular a la cápsula de la articulación acromioclavicular. Este músculo estaba inervado por un ramo del nervio subclavio. De acuerdo a su localización e inervación el músculo aberrante fue considerado como el músculo subclavio posticus. Las relaciones anatómicas del músculo tienen significancia clínica.

PALABRAS CLAVE: Músculo subclavio posticus; Variación muscular; Musculatura hipobranquial; Nervio frénico accesorio.

\section{REFERENCES}

Akita K, Ibukuro K, Yamaguchi K, Heima S, Sato T. The subclavius posticus muscle: a factor in arterial, venous or brachial plexus compression? Surg. Radiol. Anat., 22(2):111-5, 2000.

Akita K, Tsuboi Y, Sakamoto H, Sato T. A case of muscle subclavius posticus with special reference to its innervation. Surg. Radiol. Anat., 18(4):335-7, 1996.

Forcada P, Rodriguez-Niedenfuhr M, Liusa M, Carrera A. Subclavius posticus muscle: Supernumery muscle as a potential cause for thoracic outlet syndrome. Clin. Anat., 14(1):55-7, 2001.
Tanaka S, Zukeran C, Nakagawa S. A macroscopical study of the subclavius muscle of rat. Anat Anz., 165(5):417-24, 1998.

Corresponce to:

Dr Mangala Pai

Department of Anatomy, Center for Basic Sciences

Kasturba Medical College, Bejai, Mangalore- 575004

Karnataka, IXNDIA

Email:drmmpai@gmail.com

Received: 31-03-2006

Accepted: 26-08-2006 